\title{
INFLUENCE OF SEED TUBE CURVATURE ON SEED LONGITUDINAL DISTRIBUTION
}

\author{
Daniel Savi ${ }^{1 *}$, Leonardo L. Kmiecik ${ }^{1}$, Lauro Strapasson Neto ${ }^{1}$, \\ Thiago X. da Silva ${ }^{1}$, Samir P. Jasper ${ }^{1}$
}

${ }^{1 *}$ Corresponding author. Universidade Federal do Paraná - UFPR/ Curitiba - PR, Brasil.

E-mail: daniel.savi98@gmail.com | ORCID ID: https://orcid.org/0000-0002-2519-0635

\section{KEYWORDS}

Sowing uniformity, productivity, seed drill, performance monitoring, bench experiment.

\begin{abstract}
Studies on the longitudinal distribution of seeds in the sowing row seek to improve crop homogeneity, thus generating high productivity. In this context, seed tubes must be analyzed for their angular curvature. Thus, this study aimed to evaluate the influence of the seed tube curvature on the longitudinal distribution of corn and soybean seeds at different speeds. Two experiments were conducted completely randomized in a double factorial design. The first factor consisted of the seed tube curvature (straight and curved) and the second factor consisted of sowing speeds $\left(1.11,1.39\right.$, and $1.67 \mathrm{~m} \mathrm{~s}^{-1}$ for corn and $1.39,1.67,1.94$, and $2.22 \mathrm{~m} \mathrm{~s}^{-1}$ for soybean), with five replications. The parameters analyzed to measure the longitudinal distribution were the number of seeds per meter, average spacing, double, flawed, and acceptable spacings, coefficient of variation, and precision index. The results were subjected to normality and homogeneity tests of residuals, followed by an analysis of variance and Tukey test, when significant. The curved seed tube showed the highest efficiency in the measured parameters for both corn and soybean. The increase in sowing speed had a negative influence on the evaluated parameters, especially in the soybean crop.
\end{abstract}

\section{INTRODUCTION}

Seed drills must be able to cut the plant residues on the soil surface, open the sowing furrow, and deposit fertilizers and seeds evenly in an adequate spacing and depth during the process of sowing crops. Then, these machines must close the furrow and compact the soil over the seed, aiming at soil-seed contact (Mialhe, 2012). These processes are essential for contemporary agriculture, as they influence crop productivity.

The spacing between seeds within the sowing furrow is among the criteria for evaluating the longitudinal distribution of seeds by the seed drill. It can be measured under laboratory conditions to avoid the effects of external factors that could affect its efficiency and functionality (Okopnik \& Falate, 2014).

The reduction in the plantability efficiency of the seed drill directly interferes with seed distribution, promoting a higher occurrence of double or flawed spacing in the sowing furrow. Double spacing occurs when the distance between seeds does not reach 0.5 times the desired spacing, and flawed spacing refers to seeds deposited above 1.5 times the desired spacing (ISO 7256/1, 1984).

The effects caused by the heterogeneity of longitudinal distribution of seeds are worse in crops that cannot compensate for this factor, such as corn (Sangoi et al., 2019) and sunflower (Pereira \& Hall, 2019). The effect of an irregular deposition is little in crops that have phenotypic plasticity, such as soybean, but it still causes productivity losses (Beliavskaya, 2017; Büchling et al., 2017; Junior et al., 2018).

The effect of the construction shape of the seed tube stands out among the factors that influence the longitudinal distribution of seeds, varying the length, angle, and diameter of inlet and outlet (Carpes et al., 2017), in addition to the sowing speed of the seed drill (Nadin et al., 2019). This study aimed to evaluate the influence of the seed tube curvature on the longitudinal distribution of corn and soybean seeds at different sowing speeds.

\footnotetext{
${ }^{1}$ Universidade Federal do Paraná - UFPR/ Curitiba - PR, Brasil.
} 


\section{MATERIAL AND METHODS}

\section{Characterization of the test bench}

The experiment evaluated two seed tubes (straight and curved) coupled to the horizontal disc metering mechanism, simulating sowing speeds of $1.11,1.39$, and $1.67 \mathrm{~m} \mathrm{~s}^{-1}$ for corn seeds and 1.39, 1.67, 1.94, and $2.22 \mathrm{~m} \mathrm{~s}^{-1}$ for soybean seeds, totaling six treatments for corn and eight treatments for soybean. Five replications of 250 spacings were measured for each treatment, totaling 35,000 information.

The bench described in Figure 1 was used to evaluate the different seed tubes, simulating the longitudinal distribution of seeds in the sowing furrow. The bench consists of two independent sections. Section $A$ is responsible for fixing and regulating the metering mechanisms and section $\mathrm{B}$ for conducting the deposited seeds for identification by an infrared sensor.

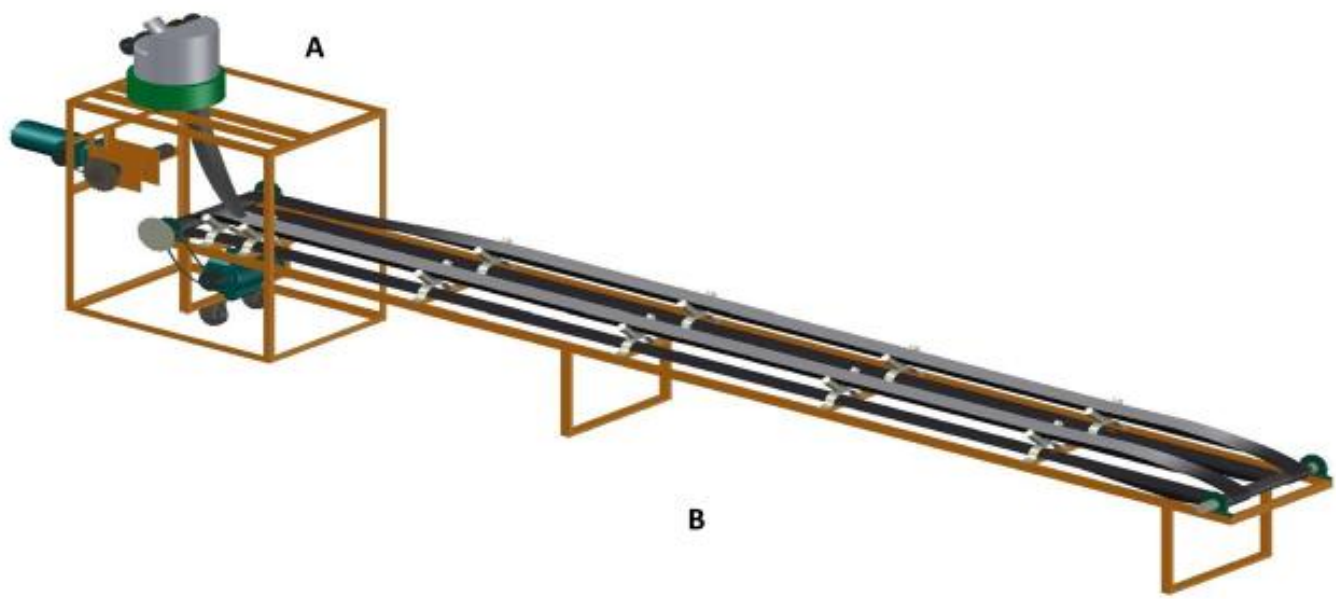

FIGURE 1. Representative diagram of the bench that simulates the longitudinal distribution of seeds. (A) Segment responsible for the metering of seeds; (B) segment responsible for the conduction and reading of seeds (B).

The metering mechanism consisted of a J. Assy ${ }^{\circledR}$ Titanium, leveled at the height of $0.53 \mathrm{~m}$ in relation to the belt conveyor. A RampFlow ${ }^{\circledR}$ disc with 28 holes in a single row $(15.5 \times 11.5 \mathrm{~mm})$ mounted on a ring with no indents was used to conduct the tests with corn. The tests with soybean used a 90 -hole $(9 \mathrm{~mm})$ disc on a three-millimeter indented ring. The activation of the seed metering mechanism used a $0.25 \mathrm{~kW}$ Sew Eurodrive ${ }^{\circledR}$ gear motor (25.37:1) managed by a Weg ${ }^{\circledR}$ CFW300 frequency inverter.
The conveyor belt was made of felt, driven by a $0.37 \mathrm{~kW} \mathrm{Weg}{ }^{\circledR}$ electric motor, with a maximum rotation of 1,150 RPM, controlled by another $\mathrm{Weg}^{\circledR}$ CFW300 frequency inverter.

\section{Treatments and experiments}

The seeds were conducted through two distinct tubes, one of them straight and another curved with a parabolic profile. Their dimensional characteristics are shown in Figure 2.

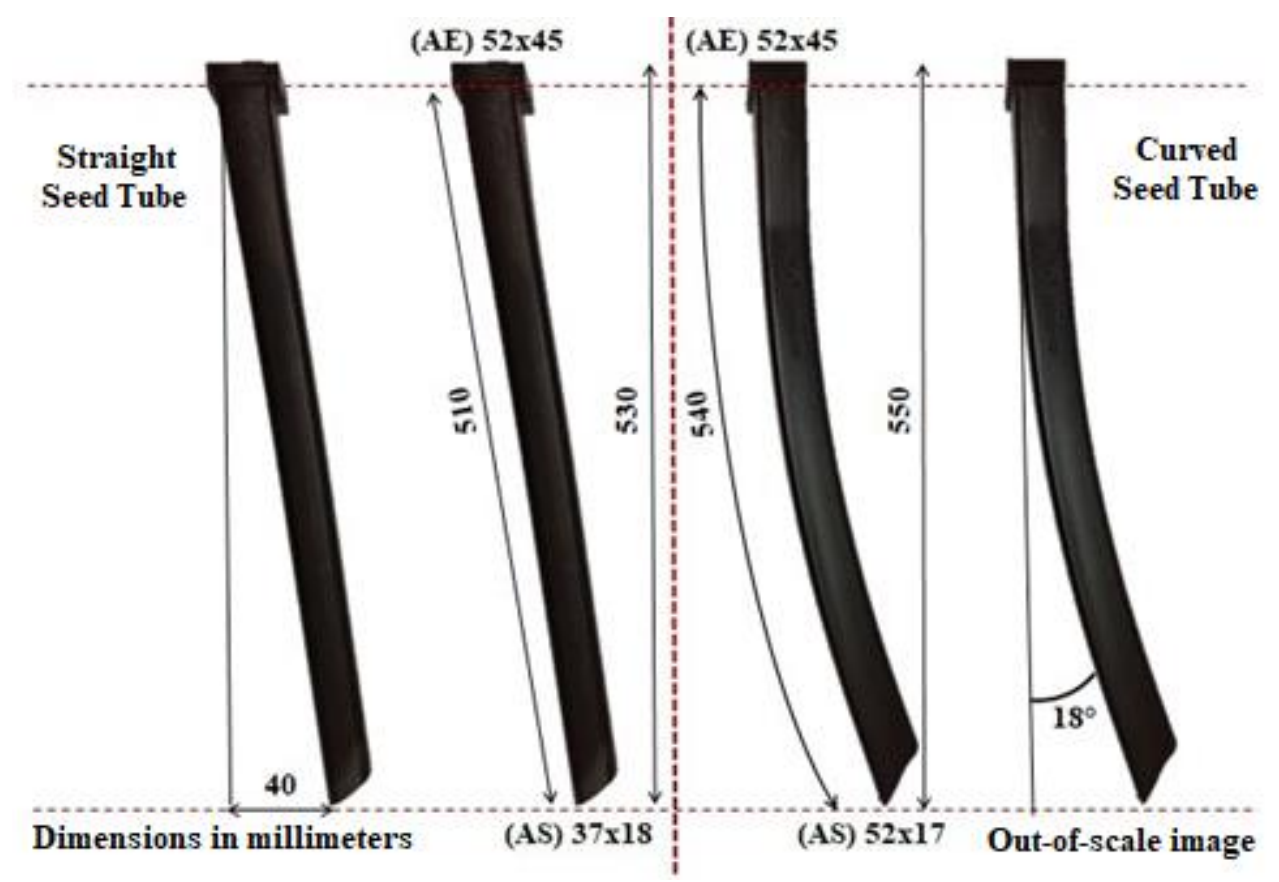

FIGURE 2. Image and specifications of the seed tubes used in the longitudinal distribution of seeds. 
Both seed tubes had infrared seed count sensors linked to a Saframax ${ }^{\circledR}$ SM3 Plus sowing monitor, providing the number of seeds deposited in each experimental plot.

The simulated sowing density for corn was 100,000 seeds per hectare, with a spacing of $0.45 \mathrm{~m}$, resulting in 4.50 seeds per meter, that is, the ideal spacing between seeds was $0.22 \mathrm{~m}$. Soybean sowing density took into account the improved efficiency in the use of solar radiation proposed by Petter et al. (2016), corresponding to 375,000 seeds per hectare, with $0.45 \mathrm{~m}$ spacing, resulting in 16.88 seeds per meter and an ideal spacing between seeds of $0.06 \mathrm{~m}$.

A correlation between the frequency of the inverter and the motor rotation for the conveyor belt was performed to maintain the seeding density at the different simulated speeds $\left(1.0 \mathrm{~Hz}=0.064 \mathrm{~m} \mathrm{~s}^{-1} ; \mathrm{R}^{2}=1.00\right)$. The number of seeds deposited per second was adjusted in the other frequency inverter, with a value of $1.0 \mathrm{~Hz}=0.16$ seeds/second for corn $\left(\mathrm{R}^{2}=0.99\right)$ and $0.53 \mathrm{seed} /$ second for soybean $\left(\mathrm{R}^{2}=0.99\right)$.

The dimensional characteristics of the seeds (length, diameter, thickness, and sphericity) were measured in 100 samples according to the methodology by Soyoye et al. (2018), using a digital caliper. Length, diameter, thickness, and sphericity were $14.5 \mathrm{~mm}, 7.4 \mathrm{~mm}, 4.0 \mathrm{~mm}$, and $52 \%$ for corn seeds and $7.7 \mathrm{~mm}, 7.6 \mathrm{~mm}, 6.5 \mathrm{~mm}$, and $95 \%$ for soybean seeds.

The angle of repose was established by the inverse tangent of the height by the distance of the deposited seeds (Baraviera et al., 2014), resulting in $23^{\circ}$ for corn and $21^{\circ}$ for soybean.

Powdered graphite (Quimidrol ${ }^{\circledR}$ ) was used at a proportion of $4 \mathrm{~g}$ for each $1 \mathrm{~kg}$ of corn seed and $2 \mathrm{~g}$ for each $1 \mathrm{~kg}$ of soybean seed (Jasper et al., 2006; Alonço et al., 2018). The seedbox of the metering mechanism had always remained complete, preventing levels below $25 \%$ to avoid failures in filling the disc (Jasper et al., 2009).

\section{Automated data acquisition}

The spacing between seeds was calculated through the sowing speed simulated by the belt conveyor and the time of passage of each seed, according to Equation (1). The times were measured using an E18-D80NK infrared proximity sensor fixed on a metal frame approximately 0.05 $\mathrm{m}$ from the belt (Karimi et al., 2017; Cay et al., 2017). In addition, another infrared sensor was strategically positioned on the cogwheel (16 teeth) on the roller that moved the belt, allowing the measurement of the simulated speed (Santos et al, 2011).

$$
\mathrm{Sp}=\left(\mathrm{T}_{2}-\mathrm{T}_{1}\right) \times \mathrm{S}
$$

Where:

Sp is the spacing $(\mathrm{m})$;

$\mathrm{T}_{1}$ is the reading time of $\mathrm{n}-1$ seeds;

$\mathrm{T}_{2}$ is the reading time of $\mathrm{n}$ seeds, and

$\mathrm{S}$ is the belt speed $\left(\mathrm{m} \mathrm{s}^{-1}\right)$.

All the generated data were processed by a printed circuit board on an Arduino platform and transferred to external HD for later tabulation and analysis.

The duration to collect each treatment corresponded to the deposition of 3,000 seeds. The initial portion of the data, numbered from 1 to 500, was discarded to guarantee the system stabilization; collections from 501 to 750 corresponded to the first replication; 1,001 to 1,250 was the second replication; 1,501 to 1,750 was the third replication; 2,002 to 2,250 represented the fourth replication, collections from 2,501 to 2,750 corresponded to the fifth replication, and the rest of the data were not used for statistical analysis.

The measured parameters consisted of the number of seeds per meter (NSM), average spacing between seeds $(\mathrm{SPX})$, percentage of double (DS), flawed (FS), and acceptable spacings (AS), coefficient of variation (CV), and precision index (PI), which is a criterion that shows the variability of the theoretical distribution of the spacing between seeds. The suggested upper limit for PI in precision seed drills is $29 \%$ (Nejadi and Raoufat, 2013), as shown in [eq. (2)].

$$
\mathrm{PI}=\frac{\mathrm{S}}{\mathrm{X}_{\text {Ideal }}} \times 100
$$

Where;

$\mathrm{P}$ is the precision index;

$\mathrm{S}$ is the standard deviation of acceptable spacings, and

$\mathrm{X}_{\text {Ideal }}$ is the expected spacing.

The performance indicators of the seed drill were evaluated using the criteria provided in Table 1 (Aykas et al., 2013; ISO 7256/1-1984 (E) Standard, 1984).

\begin{tabular}{|c|c|c|c|}
\hline \multicolumn{3}{|c|}{ Spacing (\%) } & \multirow{2}{*}{ Classification } \\
\hline Acceptable & Double & Flawed & \\
\hline$>98.6$ & $<0.7$ & $<0.7$ & Excellent \\
\hline$>90.4$ to 98.6 & $\geq 0.7$ to $<4.8$ & $\geq 0.7$ to $<4.8$ & Good \\
\hline$\geq 82.3$ to $\leq 90.4$ & $\geq 4.8$ to $\leq 7.7$ & $\geq 4.8$ to $\leq 10.0$ & Regular \\
\hline$<82.3$ & $>7.7$ & $>10.0$ & Unsatisfactory \\
\hline
\end{tabular}

TABLE 1. Limiting values of the criteria for classifying the performance of precision seed drills.

\section{Statistical analysis}

The experiment was conducted in a completely randomized design with a double factorial arrangement $(2$ $\times 3$ for corn and $2 \times 4$ for soybeans). The first factor consisted of two seed tubes (straight and curved), while the second factor consisted of simulated sowing speeds, with five replications, totaling 30 and 40 experimental units for corn and soybean, respectively.

The assumptions of normality of residues and homogeneity of variances were verified by the Shapiro Wilk and Bartlett tests, respectively. Box-Cox optimal power was applied for data transformation when necessary. The data were submitted to analysis of variance when the assumptions were met and the means were analyzed by the 
Tukey test $(p \leq 0.05)$ in case of significance, using the software Minitab ${ }^{\circledR} 18$.

\section{RESULTS AND DISCUSSION}

\section{Distribution of soybean seeds}

Seed tubes and sowing speeds showed significant isolated effects for the following parameters: number of seeds per meter (NSM), average spacing between seeds $(\mathrm{SPX})$, double (DS) and acceptable spacings (AS), coefficient of variation $(\mathrm{CV})$, and the precision index (PI). The number of flawed spacing (FS) presented a significant variation only for the type of seed tube. The interaction between seed tubes and simulated speeds significantly influenced the double, flawed, and acceptable spacings, in addition to the CV between spacings (Table 2).

The isolated effects of seed tube shapes (Table 2) showed that the straight seed tube reduced NSM $(2.42$ fewer seeds per meter) and increased SPX of soybean seeds (more $0.91 \mathrm{~cm}$ between seeds) compared to the curved seed tube. This reduction in the number of seeds per meter resulted in a decrease of 53,778 seeds per hectare at an inter-row spacing of $0.45 \mathrm{~m}$. This interference at the stand promoted higher heterogeneity in the seed distribution with the straight seed tube and, consequently, higher PI ( $4.34 \%$ more) than the curved seed tube, but both seed tubes did not exceed the upper limit of $29 \%$ (Nejadi and Raoufat, 2013).

TABLE 2. Summary of analysis of variance and test of means for two seed tubes at different sowing speeds using soybean seeds.

\begin{tabular}{|c|c|c|c|c|c|c|c|c|}
\hline \multirow{2}{*}{ Factor } & \multirow{2}{*}{$\mathbf{N S M}^{1}$} & \multirow{2}{*}{$\mathrm{SP}_{\bar{X}} \mathbf{1}(\mathbf{m m})$} & \multicolumn{3}{|c|}{ Spacing (\%) } & \multirow{2}{*}{$\begin{array}{l}\text { CV } \\
(\%)\end{array}$} & \multirow{2}{*}{$\begin{array}{c}\text { PI } \\
(\%)\end{array}$} & \multirow{2}{*}{ Classification } \\
\hline & & & Double & Flawed & Acceptable & & & \\
\hline \multicolumn{9}{|l|}{ Seed tube } \\
\hline Curved & $17.78 \mathrm{~A}$ & $56.3 \mathrm{~B}$ & $6.30 \mathrm{~B}$ & $7.50 \mathrm{~B}$ & $86.20 \mathrm{~A}$ & $38.21 \mathrm{~B}$ & $22.48 \mathrm{~B}$ & Regular \\
\hline Straight & $15.36 \mathrm{~B}$ & $65.4 \mathrm{~A}$ & $16.28 \mathrm{~A}$ & $22.25 \mathrm{~A}$ & $61.47 \mathrm{~B}$ & $62.39 \mathrm{~A}$ & $26.82 \mathrm{~A}$ & Unsatisfactory \\
\hline \multicolumn{9}{|l|}{ Sowing speed } \\
\hline $1.39 \mathrm{~m} \mathrm{~s}^{-1}$ & $17.26 \mathrm{~A}$ & $58.1 \mathrm{C}$ & $9.85 \mathrm{~B}$ & $12.00 \mathrm{C}$ & $78.15 \mathrm{~A}$ & $46.22 \mathrm{C}$ & $23.62 \mathrm{~B}$ & Unsatisfactory \\
\hline $1.67 \mathrm{~m} \mathrm{~s}^{-1}$ & $16.80 \mathrm{AB}$ & $59.8 \mathrm{BC}$ & $10.80 \mathrm{AB}$ & $14.45 \mathrm{~B}$ & $74.75 \mathrm{AB}$ & $50.16 \mathrm{~B}$ & $24.73 \mathrm{AB}$ & Unsatisfactory \\
\hline $1.94 \mathrm{~m} \mathrm{~s}^{-1}$ & $16.42 \mathrm{~B}$ & $61.6 \mathrm{~B}$ & $12.90 \mathrm{~A}$ & $16.30 \mathrm{~A}$ & $70.80 \mathrm{~B}$ & $51.04 \mathrm{~B}$ & $24.67 \mathrm{AB}$ & Unsatisfactory \\
\hline $2.22 \mathrm{~m} \mathrm{~s}^{-1}$ & $15.79 \mathrm{C}$ & $63.9 \mathrm{~A}$ & $11.60 \mathrm{AB}$ & $16.75 \mathrm{~A}$ & $71.65 \mathrm{~B}$ & $53.77 \mathrm{~A}$ & $25.56 \mathrm{~A}$ & Unsatisfactory \\
\hline \multicolumn{9}{|l|}{ F-test } \\
\hline Seed tube & $117.03^{* *}$ & $113.01^{* *}$ & $197.11^{* *}$ & $418.05^{* *}$ & $420.34^{* *}$ & $445.86^{* *}$ & $143.39^{* *}$ & \\
\hline Sowing speed & $9.55^{* *}$ & $9.09^{* *}$ & $3.30^{*}$ & $8.96^{* *}$ & $7.67^{* *}$ & $7.43^{* *}$ & $4.81^{* *}$ & \\
\hline Seed tube $\times$ speed & $2.86^{\mathrm{NS}}$ & $2.89^{\mathrm{NS}}$ & $4.05^{*}$ & $13.51^{* *}$ & $11.01^{* *}$ & $9.24^{* *}$ & $0.43^{\mathrm{NS}}$ & \\
\hline $\mathrm{CV}(\%)$ & 2.28 & 2.51 & 17.80 & 13.72 & 4.62 & 6.44 & 1.36 & \\
\hline Normality (SW) & 0.04 & 0.05 & 0.68 & 0.68 & 0.54 & 0.33 & 0.65 & \\
\hline Homogeneity $\left(\mathrm{B}_{0}\right)$ & 0.77 & 0.63 & 0.62 & 0.18 & 0.48 & 0.67 & 0.99 & \\
\hline
\end{tabular}

${ }^{1}$ Variables transformed with the Box-Cox tool due to lack of normality. Means followed by the same uppercase letter in each column within each factor do not differ from each other by the Tukey test $(\mathrm{P}<0.05)$. F-test for analysis of variance (ANOVA): NS - Not significant, * $(\mathrm{P}<0.05)$, and $* *(\mathrm{P}<0.01)$. Shapiro-Wilk normality test: $\mathrm{SW} \leq 0.05$ - data abnormality and $\mathrm{SW}>0.05$ - data normality. Bartlett's test for homogeneity of variances: $\mathrm{B}_{0} \leq 0.05$ - heterogeneous variances; $\mathrm{B}_{0}>0.05$ - homogeneous variances.

The influence of simulated speeds on the variables was less expressive, but an increase in sowing speed reduced NSM and AS, increasing SPX, DS, FS, CV, and PI. In this case, a reduction of approximately 0.5 seeds deposited in each meter was observed proportionally to the increase of $0.28 \mathrm{~m} \mathrm{~s}^{-1}\left(1.0 \mathrm{~km} \mathrm{~h}^{-1}\right)$, corresponding to the reduction found by Pinheiro Neto et al. (2009) as a consequence of an increase in the average spacing between $2-\mathrm{mm}$, in addition to increasing PI by $0.65 \%$.

The straight seed tube promoted increases in DS
(9.98\%), FS (14.75\%), and CV (24.18\%), thus reducing the number of AS (-24.73\%) of soybean seeds regardless of the sowing speed (Figure 3 ). The curved seed tube promoted no variation at the different spacings (DS, FS, and AS) and CV with a variation in sowing speed.

However, the straight seed tube at the sowing speed of $1.39 \mathrm{~m} \mathrm{~s}^{-1}$ provided the lowest values of DS, FS, and CV, besides the highest percentage of AS compared to the other sowing speeds (Figure 3), demonstrating it is the best speed when working with this tube shape. 
(a)

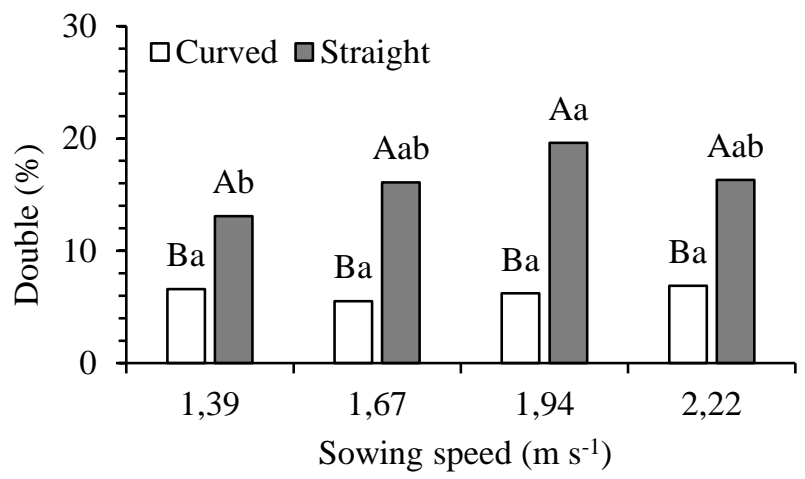

(c)

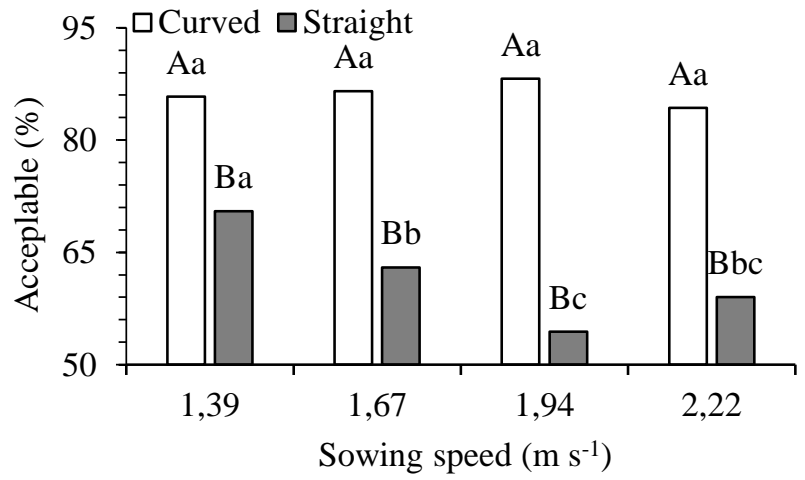

(b)

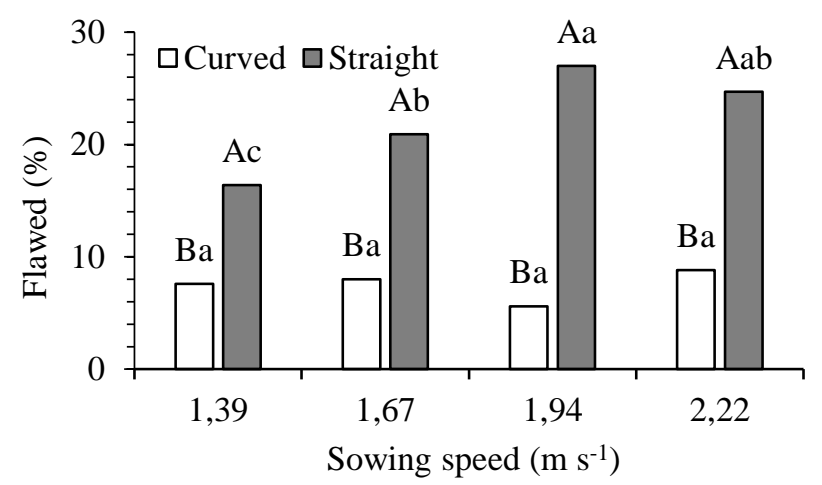

(d)

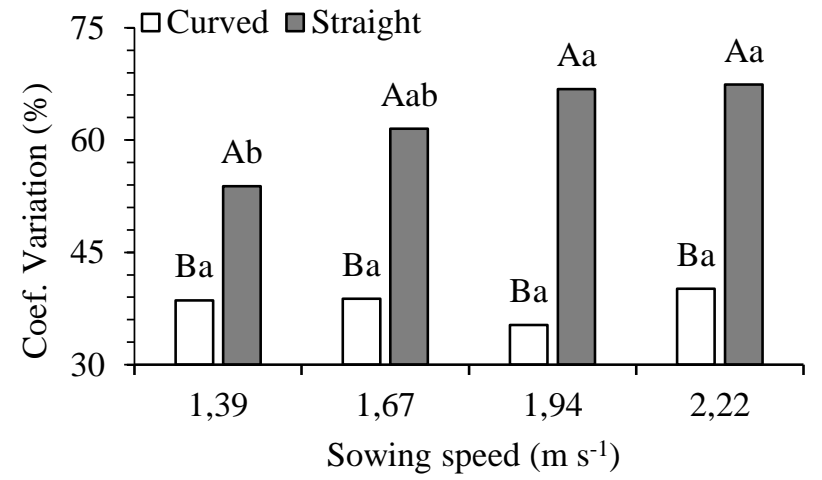

FIGURE 3. Effects of the seed tube shape and sowing speed on double (a), flawed (b), and acceptable spacings (c), and coefficient of variation (d) of soybean seed spacings. Means followed by the same uppercase letter between seed tubes and the same lowercase letter between sowing speeds do not differ from each other by the Tukey test $(p \leq 0.05)$.

The simulated sowing speed showed no significant influence on the number of double, flawed, and acceptable spacings (Figure 3a, 3b, and 3c) for the curved seed tube, but the straight seed tube showed a significant decrease in these parameters as sowing speed increased.

The percentage of flawed spacing increased with an increase in sowing speed, resulting in a reduction of the acceptable spacing in the following order: $1.39>1.67>$ $1.94 \mathrm{~m} \mathrm{~s}^{-1}$. However, the sowing speed of $2.22 \mathrm{~m} \mathrm{~s}^{-1}$ resulted in flawed and acceptable spacing levels similar to those of sowing speeds of 1.67 and $1.94 \mathrm{~m} \mathrm{~s}^{-1}$ (Figures 3b and $3 \mathrm{c}$ ).

The lowest coefficient of variation of the straight seed tube was observed at the lowest simulated speed, resulting in a more uniform distribution compared to the others. However, sowing speeds of $1.67,1.94$, and $2.22 \mathrm{~m} \mathrm{~s}^{-1}$ did not differ from each other (Figure 3d) and the curved seed tube showed no significant difference in this parameter.

The increased double and flawed spacings, which results in an increase in the $\mathrm{CV}$ of spacings and a reduction in the acceptable spacing (Figure 3), can be attributed to a higher rebound of the seeds inside the straight seed tube compared to the curved seed tube (Carpes et al., 2016), worsening with an increase in the simulated speed. This result corroborates with Dias et al. (2014), who observed higher distribution regularity at lower peripheral speeds of the horizontal sowing disc.
According to Cay et al. (2018), high peripheral speeds of the horizontal disc provide a high angle of impact of the seed in the seed tube, generating a ricochet through it. It causes delays in the fall of seeds, leading to an irregular deposition in the furrow (Nascimento et al., 2015).

Therefore, this mechanical metering system (horizontal disc) with the curved seed tube was classified as regular at all simulated sowing speeds. However, the straight seed tube presented an unsatisfactory behavior in all evaluated scenarios. The straight seed tube was less efficient in the distribution of seeds, but their damage may be enhanced at higher sowing speeds (Figure 3), making it difficult to fill the alveoli in the horizontal disk of the seed drill, providing a high number of flawed spacing and increased average spacing between seeds (Alonço et al., 2018).

\section{Distribution of corn seeds}

Seed tubes showed a significant effect on the number of seeds per meter (NSM), average spacing between seeds (SPX), double, flawed, and acceptable spacings and their variation coefficient $(\mathrm{CV})$, and the precision index (PI). On the other hand, sowing speed variation resulted in significant effects only on PI. The interaction between seed tubes and simulated speeds significantly influenced double, flawed, and acceptable spacings, coefficient of variation (CV), and precision index (PI) between spacings (Table 3). 
TABLE 3. Summary of analysis of variance and test of means for two seed tubes at different sowing speeds using corn seeds.

\begin{tabular}{|c|c|c|c|c|c|c|c|c|}
\hline \multirow{2}{*}{ Factor } & \multirow{2}{*}{$\mathbf{N S M}^{1}$} & \multirow{2}{*}{$\operatorname{SP}^{1}(\mathbf{m m})$} & \multicolumn{3}{|c|}{ Spacing (\%) } & \multirow{2}{*}{$\begin{array}{l}\text { CV } \\
(\%)\end{array}$} & \multirow{2}{*}{$\underset{(\%)}{\text { PI }}$} & \multirow{2}{*}{ Classification } \\
\hline & & & Double & Flawed & Acceptable & & & \\
\hline \multicolumn{9}{|l|}{ Seed tube } \\
\hline Curved & $4.98 \mathrm{~A}$ & $200.9 \mathrm{~B}$ & $3.30 \mathrm{~B}$ & $5.47 \mathrm{~B}$ & $91.23 \mathrm{~A}$ & $30.09 \mathrm{~B}$ & $11.82 \mathrm{~B}$ & Regular \\
\hline Straight & $4.84 \mathrm{~B}$ & $206.4 \mathrm{~A}$ & $9.37 \mathrm{~A}$ & $9.16 \mathrm{~A}$ & $81.47 \mathrm{~B}$ & $42.67 \mathrm{~A}$ & $19.51 \mathrm{~A}$ & Unsatisfactory \\
\hline \multicolumn{9}{|l|}{ Sowing speed } \\
\hline $1.11 \mathrm{~m} \mathrm{~s}^{-1}$ & 4.96 & 201.7 & 6.85 & 6.40 & 86.75 & 36.87 & $15.17 \mathrm{~B}$ & Regular \\
\hline $1.39 \mathrm{~m} \mathrm{~s}^{-1}$ & 4.90 & 204.3 & 5.30 & 7.35 & 87.35 & 36.14 & $15.35 \mathrm{~B}$ & Regular \\
\hline $1.67 \mathrm{~m} \mathrm{~s}^{-1}$ & 4.88 & 204.9 & 6.85 & 8.20 & 84.95 & 36.15 & $16.48 \mathrm{~A}$ & Regular \\
\hline \multicolumn{9}{|l|}{ F-test } \\
\hline Seed tube & $13.69^{* *}$ & $12.61^{* *}$ & $40.10^{* *}$ & $33.70^{* *}$ & $58.41^{* *}$ & $66.07^{* *}$ & $323.45^{* *}$ & \\
\hline Sowing speed & $2.11^{\mathrm{NS}}$ & $1.66^{\mathrm{NS}}$ & $1.16^{\mathrm{NS}}$ & $2.66^{\mathrm{NS}}$ & $1.27^{\mathrm{NS}}$ & $0.10^{\mathrm{NS}}$ & $3.64^{*}$ & \\
\hline Seed tube $\times$ speed & $0.63^{\mathrm{NS}}$ & $0.66^{\mathrm{NS}}$ & $8.833^{* *}$ & $4.01^{*}$ & $9.97^{* *}$ & $7.07^{* *}$ & $3.83^{*}$ & \\
\hline $\mathrm{CV}(\%)$ & 1.81 & 1.85 & 37.05 & 21.34 & 3.62 & 10.42 & 1.24 & \\
\hline Normality (SW) & 0.12 & 0.17 & 0.79 & 0.88 & 0.71 & 0.69 & 0.60 & \\
\hline Homogeneity $\left(\mathrm{B}_{0}\right)$ & 0.95 & 0.98 & 0.04 & 0.88 & 0.12 & 0.38 & 0.71 & \\
\hline
\end{tabular}

${ }^{1}$ Variables transformed with the Box-Cox tool due to lack of normality. Means followed by the same uppercase letter in each column within each factor do not differ from each other by the Tukey test $(\mathrm{P}<0.05)$. F-test for analysis of variance (ANOVA): NS - Not significant, * $(\mathrm{P}<0.05)$, and $* *(\mathrm{P}<0.01)$. Shapiro-Wilk normality test: $\mathrm{SW} \leq 0.05$ - data abnormality and $\mathrm{SW}>0.05$ - data normality. Bartlett's test for homogeneity of variances: $\mathrm{B}_{0} \leq 0.05$ - heterogeneous variances; $\mathrm{B}_{0}>0.05$ - homogeneous variances.

The isolated effects of seed tube shapes showed that the straight seed tube reduced NSM ( 0.14 fewer seeds per meter) and increased SPX between seeds by $5.5 \mathrm{~mm}$ compared to the curved seed tube. This reduction in the number of seeds per meter resulted in a decrease of 3,111 seeds per hectare, that is, a reduction of $3.11 \%$ of the preestablished stand, affecting its morphological characteristics due to the phenological plasticity of the crop (Sangoi et al., 2019).

(a)

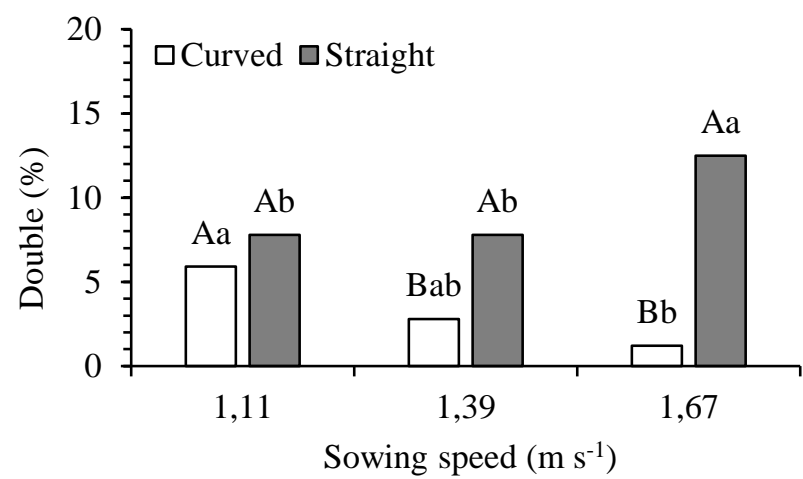

Seed tube shape significantly interfered with the homogeneity of seed distribution. The use of the straight seed tube increased the frequency of DS (6.07\%) and FS $(3.69 \%)$, which led to a reduction in the number of $\mathrm{AS}$ $(-9.76 \%)$, regardless of the adopted sowing speed. Thus, the CV was $12.58 \%$ higher in the straight seed tube, resulting in a worse PI $(-7.69 \%)$ compared to the curved seed tube (Table 4).

(b)

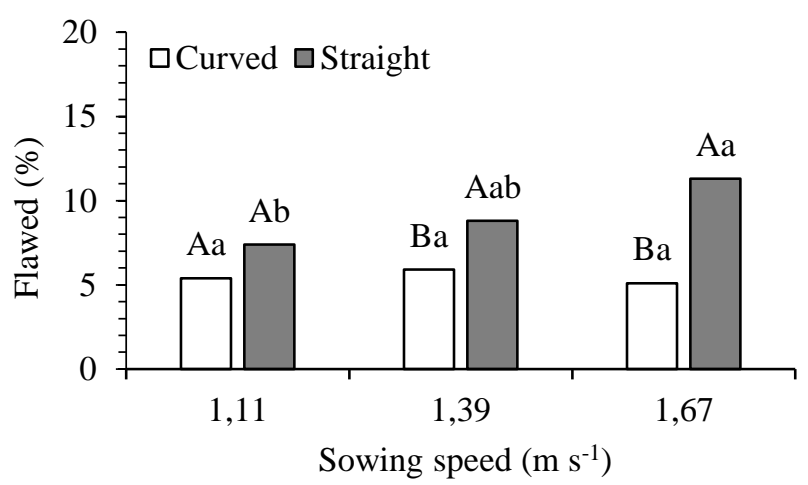


(c)

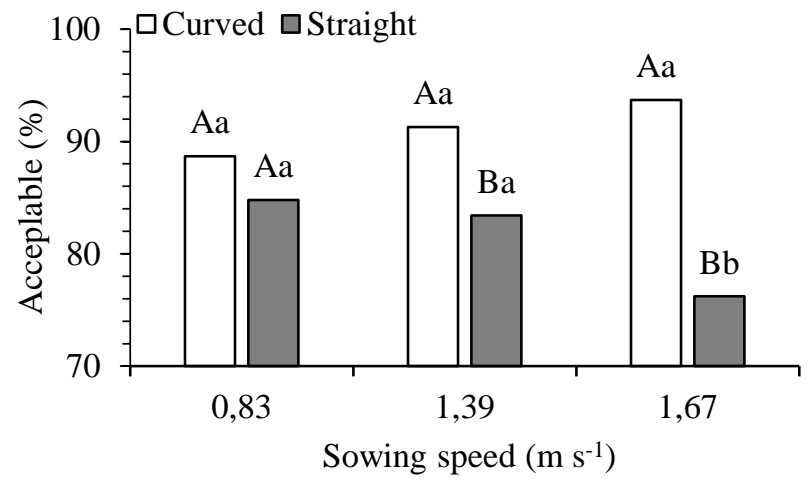

(d)

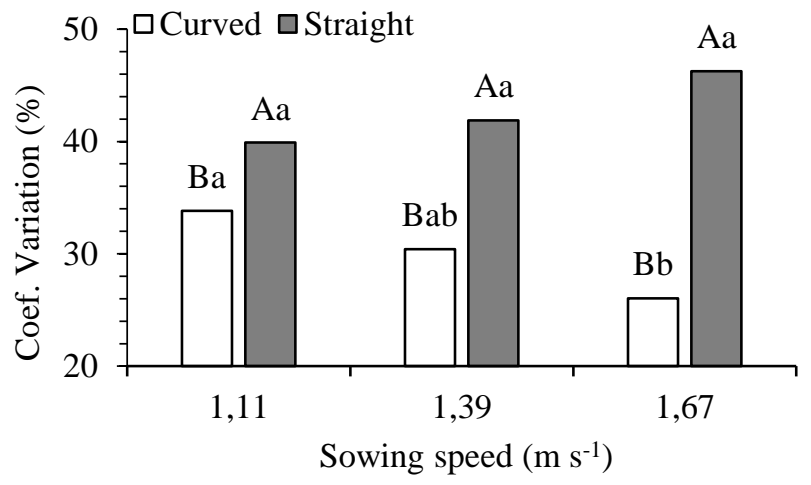

(e)

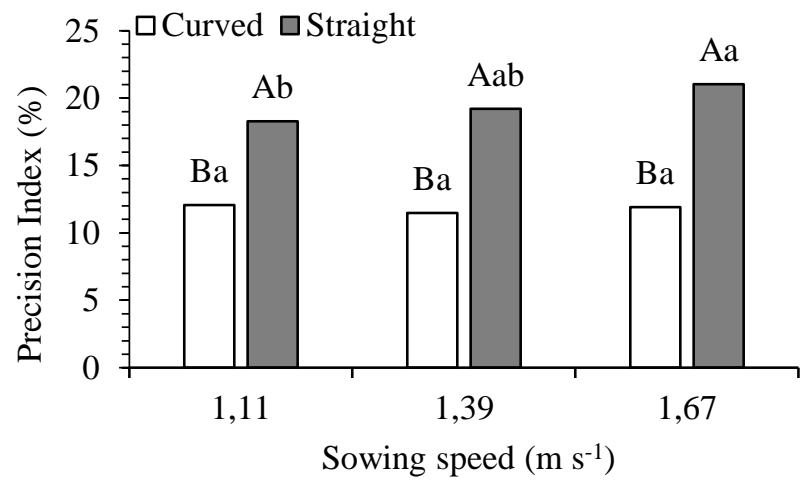

FIGURE 4. Effects of the seed tube shape and sowing speed on double (a), flawed (b), and acceptable spacings (c), coefficient of variation (d), and precision index (e) of corn seed spacings. Means followed by the same uppercase letter between seed tubes and the same lowercase letter between sowing speeds do not differ from each other by the Tukey test $(p \leq 0.05)$.

Double and flawed spacings showed similar behavior for seed tubes and sowing speeds (Figures $4 \mathrm{a}$ and 4b). In both situations, the curved seed tube had lower values than the straight tube. The increased sowing speed led to a reduction in the occurrence of double spacings using the curved seed tube, with the intermediate speed not differing from the others, with no significant difference in the flawed spacings.

The increased sowing speed led to an increase in the number of double spacings in the straight seed tube (Figure 4a), with the highest sowing speed being statistically higher than the others. Similar behavior was observed in the flawed spacings, in which the sowing speed of $1.67 \mathrm{~m} \mathrm{~s}^{-1}$ had a statistically higher value, not differing from the intermediate speed, which, in turn, remained the same as the lowest speed. A similar situation occurred in the flawed spacings (Figure $4 \mathrm{~b}$ ), in which the sowing speed of $1.67 \mathrm{~m} \mathrm{~s}^{-1}$ had a statistically higher value, not differing from the intermediate speed, which, in turn, remained the same as the lowest speed.

The acceptable spacing for both seed tubes showed similar behavior at the lowest speed, differing from the others (Figure 4c). Also, the curved seed tube remained stable for the other speeds, while the straight seed tube showed a significant reduction in the number of acceptable spacings. The behavior of this parameter was directly reflected in the coefficient of variation of the seed distribution, with the straight seed tube remaining stable and presenting worse values compared to the curved seed tube, which presented a reduction in the coefficient of variation with an increase in the simulated speed (Figure 4d).
The results of the interaction for the corn crop showed that the mechanical metering system (horizontal disc) with the curved seed tube was classified as good at all simulated speeds. However, the straight seed tube presented a regular behavior at the lowest speeds $\left(1.11\right.$ and $1.39 \mathrm{~m} \mathrm{~s}^{-1}$ ) and an unsatisfactory behavior at the speed of $1.67 \mathrm{~m} \mathrm{~s}^{-1}$.

Corn seed distribution was more homogeneous (precision index) in the curved seed tube at all simulated speeds (Figure 4e). Carpes et al. (2017) reported better efficiencies for corn seed distribution using the curved seed tube due to a reduction in the seed fall speed promoted by the parabolic profile of the tube, promoting smoother seed flowability to the furrow.

\section{CONCLUSIONS}

Seed deposition was influenced by the seed tube shape, interfering with the uniformity of seed distribution in the sowing furrow. The seed tube had a higher intervention on the distribution of soybean seeds due to their higher sphericity.

The curved seed tube showed higher plantability indices than the straight seed tube due to the lower generation of multiple paths during the seed flow through it.

The increase in sowing speed negatively affected the uniformity of distribution mainly due to an increase in the number of failures caused by the poor filling of the horizontal disc. 


\section{REFERENCES}

Alonço PA, Santos AA dos, Moreira AR, Carpes DP, Lima Pires A de (2018) Distribuição longitudinal de sementes de soja com diferentes tratamentos fitossanitários e densidades de semeadura. Revista Engenharia na Agricultura 26(1):58-67.

Aykas E, Yalçin H, Yazgi A (2013) Balta tipi gömücü ayağa sahip tek dane ekim makinalarının farklı bölgelerde mısır ekiminde ekim performanslarının karşılaştırılması. Tarım Makinaları Bilimi Dergisi 9(1):67-72.

Baraviera CMC, Caneppele C, Dourado LGA, Aguero NF (2014) Avaliação de propriedades físicas de grãos de híbridos de milho. Enciclopédia Biosfera - Centro Científico Conhecer 10(19):291-297.

Beliavskaya L (2017) The results of study of ecological stability and plasticity of Ukrainian soybean varieties. Annals of Agrarian Science 15(2):247-251. DOI: http://dx.doi.org/10.1016/j.aasci.2017.05.003.

Büchling C, Oliveira Neto AM de, Guerra N, Bottega EL (2017) Uso da plasticidade morfológica como estratégia para a redução da população de plantas em cultivares de soja. Agrarian 10(35):22-30.

Cay A, Kocabiyik H, May S (2018) Development of an electro-mechanic control system for seed-metering unit of single seed corn planters Part I: Design and laboratory simulation. Computers and Electronics in Agriculture 144:71-79.

Cay A, Kocabiyik H, Karaaslan B, May S, Khurelbaatar M (2017) Development of an opto-electronic measurement system for planter laboratory tests. Measurement 102:90-95.

Carpes DP, Alonço AS, Rossato FP, Veit AA, Souza LB, Francetto TR (2017) Effect of different conductor tubes on the longitudinal distribution of corn seeds. Revista Brasileira de Engenharia Agrícola e Ambiental 21:657-662.

Carpes DP, Santos Alonco A, Rodrigo Francetto T, Franck CJ, Belle MP, Costa Machado OD da (2016) Efeito de diferentes tubos condutores na distribuição longitudinal de sementes de soja. Revista Brasileira de Ciência das Culturas 10(8):1144.

Dias VDO, Alonço ADS, Carpes DP, Veit AA, Souza LBD (2014) Peripheral speed of the plate in seed meters of corn and soybean. Ciência Rural 44(11):1973-1979.

ISO 7256/1 (1984) Standard. Sowing equipment-test methods e Part one, single seed drills (precision drills), 7256/1, International Organisation for Standardization. ISO, 3 ed.

Jasper R, Justino A, Morgado CB, Dyck R, Garcia LC (2009) Comparação de bancadas simuladoras do processo de semeadura em milho. Revista Engenharia Agrícola 29(4):623-629.
Jasper R, Janszen U, Jasper M, Garcia LC (2006)

Distribuição longitudinal e germinação de sementes de milho com emprego de tratamento fitossanitário e grafite. Engenharia Agrícola 26(1):292-299.

Junior AAB, Oliveira MCN de, Zucareli C, Sampaio A, Ferreira FW, Silva MADA (2018) Analysis of phenotypic plasticity in indeterminate soybean cultivars under different row spacing. Australian Journal of Crop Science 12(4):648.

Karimi H, Navid H, Besharati B, Behfar H, Eskandari I (2017) A practical approach to comparative design of noncontact sensing techniques for seed flow rate detection. Computers and electronics in agriculture 142:165-172..

Mialhe LG (2012) Máquinas agrícolas para plantio. Campinas, Millennium, p 4.

Nadin W, Pereira PSX, Rondon OHS, Afonso MF, Pallaoro DS, Camili EC, Silva ARB da (2019) Effect of the Sowing Speed on the Distribution Regularity of Maize Seeds. Journal of Experimental Agriculture International :1-8.

Nascimento JMD, Furlani CE, Chioderoli CA, Queiroz RFD, Bertonha RS, Cavichioli FA (2015) Grain yield of corn at different population densities and intercropped with forages. Revista Brasileira de Engenharia Agrícola e Ambiental 19(12):1143-1147.

Okopnik DL, Falate R (2014) Usage of the DFRobot RBDFR-49 Infrared Sensor to detect maize seed passage on a conveyor belt. Computers and electronics in agriculture 102:106-111.

Pereira ML, Hall AJ (2019) Sunflower oil yield responses to plant population and row spacing: Vegetative and reproductive plasticity. Field crops research 230:17-30.

Petter FA, Silva JD, Zuffo AM, Andrade FR, Pacheco LP, Almeida FD (2016) Elevada densidade de semeadura aumenta a produtividade da soja? Respostas da radiação fotossinteticamente ativa. Bragantia 75(2):173-183.

Pinheiro Neto R, Braccini ADL, Scapim CA, Bortolotto VC, Pinheiro AC (2008) Desempenho de mecanismos dosadores de sementes em diferentes velocidades e condições de cobertura do solo. Acta Scientiarum. Agronomy 30:611-617.

Sangoi L, Schmitt A, Durli MM, Leolato LS, Coelho AE, Kuneski HF, Vander de Liz O (2019) Estratégias de manejo do arranjo de plantas visando otimizar a produtividade de grãos do milho. Revista brasileira de milho e sorgo 18(1):47-60.

Soyoye BO, Ademosun OC, Agbetoye LA (2018) Determination of some physical and mechanical properties of soybean and maize in relation to planter design. Agricultural Engineering International: CIGR Journal 20(1):81-89. 